\title{
Development of a Chronic Kidney Disease Model in C57BL/6 Mice with Relevance to Human Pathology
}

\author{
Linghong Huang $^{\mathrm{a}} \quad$ Alessandra Scarpellini $^{\mathrm{b}} \quad$ Muriel Funck $^{\mathrm{c}}$ \\ Elisabetta A.M. Verderio ${ }^{b}$ Timothy S. Johnson ${ }^{\text {a }}$ \\ ${ }^{a}$ Academic Nephrology Unit, Sheffield Kidney Institute, University of Sheffield, Sheffield, bSchool of Science and Technology, \\ Biomedical, Life and Health Research Centre, Nottingham Trent University, and 'School of Science and Technology, Chemistry and
} Forensic Science, Nottingham Trent University, Nottingham, UK

\section{Key Words}

Aristolochic acid nephropathy $\cdot$ C57BL/6 mice $\cdot$ Chronic kidney disease $\cdot$ Extracellular matrix • Fibrosis

\begin{abstract}
Background: Genetically modified mice are used to investigate disease and assess potential interventions. However, research into kidney fibrosis is hampered by a lack of models of chronic kidney disease (CKD) in mice. Recently, aristolochic acid nephropathy (AAN), characterised by severe tubulointerstitial fibrosis, has been identified as a cause of end stage kidney disease and proposed as a model of CKD. Published studies have used various dosing regimens, species and strains, with variable outcomes. Therefore, we aimed to develop a standardised protocol to develop tubulointerstitial fibrosis using pure aristolochic acid I (AAI) in C57BL/6 mice. Methods: AAl dose optimisation was performed by intraperitoneal injection of AAl at varying dose, frequency and duration. Kidney function was assessed by serum creatinine. Fibrosis was quantified by hydroxyproline levels and Masson's Trichrome staining. Specific collagens were measured by immunofluorescent staining. Results: Single doses of AAl of $>10 \mathrm{mg} / \mathrm{kg}$ caused acute kidney failure and death. Lower doses of 2.5 $\mathrm{mg} / \mathrm{kg}$ needed to be administrated more than weekly to cause significant fibrosis. $3 \mathrm{mg} / \mathrm{kg}$ once every 3 days for 6 weeks followed by a disease development time of 6 weeks after AAl led to reduced kidney weight and function. Substantial tubulointerstitial fibrosis occurred, with males more severely affected. Increased deposition of collagen I, III and IV contributed to fibrosis, with collagen III and IV higher in males. Conclusions: AAN can be induced in C57BL/ 6 mice. The regimen of $3 \mathrm{mg} /$ kg every 3 days for 6 weeks followed by 6 weeks of disease development time gives substantial tubulointerstitial fibrosis with lesions similar to those in humans.

Copyright $\odot 2013$ S. Karger AG, Basel
\end{abstract}

The results presented in this paper have not been published previously in whole or in part, except in abstract format. 


\section{Introduction}

Chronic kidney disease (CKD) leads to end stage kidney failure (ESKF) through a progressive scarring and fibrotic process irrespective of the initiating disease. One of the best tools we have in understanding the biology of fibrosis is the use of genetically modified mice. Many genetically modified mice have been generated on a C57BL/6 background $[1,2]$ due to several significant advantages of this strain [3]. However, ESKF research is hampered by a lack of both aggressive and relevant models of CKD in mice and especially in the fibrosis resistant C57BL/6 strain. Therefore, costly and time-consuming back crossing onto other suitable strains is often required.

The most commonly used mouse model is the unilateral ureteral obstruction (UUO) model [4]. While the UUO model works in C57BL/6 mice [5], the biggest problem is that this model does not provide data on kidney function or proteinuria, both of which are essential for proper assessment of any gene manipulation or intervention. Although UUO induces inflammatory tubulointerstitial fibrosis, the generation of scar tissue is mild in C57BL/6 mice. In addition, the UUO model is complicated by the extensive nephrosis that engulfs the kidney with time and interferes with assessment of fibrosis in more advanced disease. The streptozotocin model of diabetic nephropathy in mice is highly variable and it is experimentally difficult to find a balance between hyperglycaemia and death in mice, especially in the $\mathrm{C} 57 \mathrm{BL} / 6$ strain. The $\mathrm{db} / \mathrm{db}$ mouse model of diabetic nephropathy shows a slow development of fibrosis [6] and is complicated when needing to cross with genetically modified mice. In C57BL/6 mice, the 5/6 subtotal nephrectomy fails to show any interstitial change with insignificant glomerulosclerosis [7], although this model does work in 129SV mice [8]. Protein overload instigates acute kidney failure rather than CKD, and a strain-dependent variability in disease development has been reported, with C57BL/6 mice being the least responsive strain [9]. Puromycin aminonucleoside and adriamycin nephropathies do not work as models of focal segmental glomerulosclerosis in most mouse strains, although BALB/c is partially susceptible. Therefore, there is a clear requirement to develop mouse models of CKD in C57BL/6 mice that mirror human pathology.

Recently, aristolochic acid nephropathy (AAN) has been recognised as a cause of CKD. It was first reported in Belgium in the early 1990s when two women following a weight loss program rapidly developed ESKF [10]. An epidemiological survey revealed other patients who had similar disease also attended the same weight loss program. All patients used slimming pills that contained the Chinese medicinal herb [10] aristolochic acid (AA) [11-16]. Morphologically, AAN is characterised predominantly by hypocellular interstitial scarring with small focal pockets of hypercellular interstitial fibrosis, both of which lead to tubular atrophy. Disease is more marked in the medullary ray and the outer cortex, with the glomeruli relatively spared [11, 17]. Kidneys from AAN patients are typically smaller [18]. Findings of increased low molecular weight proteins ( $\alpha 1$-microglobulin, $\beta 2$-microglobulin, cystatin C, Clara cell protein and retinal-binding protein) [19], with decreased neutral endopeptidase (an ectoenzyme of the proximal tubule brush border) in the urine from AAN patients [20], indicated that proximal tubular epithelial cells are the main target of AA.

AAN patients may present with anaemia, mild proteinuria, glycosuria or leukocyturia, normal to mildly elevated blood pressure and increased serum creatinine [21]. AAN can rapidly progress to ESKF and the progression of the disease can continue despite removing exposure to AA [22]. Approximately $2 / 3$ of AAN patients require renal replacement therapy.

The exact mechanism of how AA causes CKD is unknown. Current findings show that aristolochic acid I (AAI) induces severe reduction of peritubular capillaries resulting in hypoxia and tubular cell death $[23,24]$. AAI also decreased epidermal growth factor (EGF) expression in tubular epithelial cells, suggesting lack of regeneration in these cells. This was also 
Nephron Extra 2013;3:12-29

DOI: 10.1159/000346180

Published online: January 11, 2013

2013 S. Karger AG, Basel

www.karger.com/nne

Huang et al.: Development of a Chronic Kidney Disease Model in C57BL/6 Mice with

Relevance to Human Pathology

Table 1. Different regimens used in the literature to induce AAN in mice

\begin{tabular}{|c|c|c|c|c|c|}
\hline Strain & Dosage & $\begin{array}{l}\text { Treatment period (total } \\
\text { experimental period) }\end{array}$ & $\begin{array}{l}\text { AA } \\
\text { components }\end{array}$ & $\begin{array}{l}\text { Level of kidney damage } \\
\text { described }\end{array}$ & Ref. \\
\hline NMRI & $\begin{array}{l}10-120 \mathrm{mg} / \mathrm{kg} \text { (orally) } \\
17-125 \mathrm{mg} / \mathrm{kg} \text { (i.v.) }\end{array}$ & Single dose (up to 15 days) & $\begin{array}{l}\text { AAI }(77 \%) / \\
\text { AAII }(21 \%)\end{array}$ & $\begin{array}{l}\text { Extensive tubular necrosis } \\
\text { throughout the cortex }\end{array}$ & 27 \\
\hline FVB & 5 mg/kg/day (i.p.) & 14 days ( 3 or 6 weeks) & $\begin{array}{l}\text { AAI }(44 \%) / \\
\text { AAII }(56 \%)\end{array}$ & $\begin{array}{l}\text { Tubular degeneration with } \\
\text { mild interstitial fibrosis }\end{array}$ & 28 \\
\hline C57BL/6 & $\begin{array}{l}2.5 \mathrm{mg} / \mathrm{kg} / \text { day } \\
\text { (orally or i.p.) }\end{array}$ & $\begin{array}{l}5 \text { days a week for } 2 \text { weeks } \\
\text { ( } 2 \text { or } 4 \text { weeks) }\end{array}$ & $\begin{array}{l}\text { AAI }(55 \%) / \\
\text { AAII }(45 \%)\end{array}$ & $\begin{array}{l}\text { Mild and focal } \\
\text { tubulointerstitial changes }\end{array}$ & 29 \\
\hline $\mathrm{C} 3 \mathrm{H} / \mathrm{He}$ & $\begin{array}{l}2.5 \mathrm{mg} / \mathrm{kg} / \text { day } \\
\text { (orally or i.p.) }\end{array}$ & 9 days (10 or 24 days) & AAI $(100 \%)$ & $\begin{array}{l}\text { Acute tubular necrosis and } \\
\text { extensive cortical } \\
\text { interstitial fibrosis }\end{array}$ & 25 \\
\hline C57BL/6 & 10 or 20 mg/kg (i.p.) & Single dose (28 days) & AAI (100\%) & $\begin{array}{l}\text { Hypocellular interstitial } \\
\text { fibrosis, tubular atrophy }\end{array}$ & 31 \\
\hline $\begin{array}{l}\mathrm{C} 57 \mathrm{BL} / 6+ \\
129 / \mathrm{SV}\end{array}$ & 10,20 or $30 \mathrm{mg} / \mathrm{kg}$ (i.p.) & Single dose (28 days) & AAI (100\%) & $\begin{array}{l}\text { Hypocellular interstitial } \\
\text { fibrosis, tubular atrophy }\end{array}$ & 30 \\
\hline C57BL/6 & 5 mg/kg/day (i.p.) & $\begin{array}{l}\text { Once every } 2 \text { days for } 4 \\
\text { weeks ( } 4 \text { weeks) }\end{array}$ & $\begin{array}{l}\text { AAI }(65 \%) / \\
\text { AAII }(27 \%)\end{array}$ & $\begin{array}{l}\text { Severe tubulointerstitial } \\
\text { fibrosis }\end{array}$ & 32 \\
\hline
\end{tabular}

i.v. = Intravenous; i.p. $=$ intraperitoneal.

confirmed by the negative proliferating cell nuclear antigen (PCNA) staining in tubular cells from AAN patients [24]. Furthermore, AAI increased the expression of fibrogenic cytokines transforming growth factor $\beta 1$ (TGF $\beta 1$ ) and connective tissue growth factor (CTGF) [24]. Taken together, AAI induces an irreversible tubule damage causing tubulointerstitial fibrosis.

AA is found in Aristolochia and Asarum species. It has 11 derivatives with AAI and aristolochic acid II (AAII) being prevalent. Both AAI and AAII are potentially carcinogenic, but only AAI has a nephrotoxic effect [25]. While the kidney is the primary target organ of AAI due to AAI being concentrated in urine, AAI-DNA adducts have been found in kidney, bladder, stomach, intestine, liver, spleen, lung and brain [26] suggesting widespread distribution.

So far, the few CKD studies using AAN in mice have employed a large variation in dosing regimens, ranging from single high doses to daily low doses as well as a variable composition of AA. Furthermore, a wide variety of mice strains have been used (table 1). Most importantly, in these studies AA induced either acute kidney failure or just mild changes in kidney fibrosis [25, 27-29]. Most studies failed to show convincing images of kidney fibrosis [30-32]. Therefore, in this study, we aimed to develop a standardised protocol of kidney fibrosis in C57BL/6 mice using pure AAI, with extensive characterisation of tubulointerstitial fibrosis to demonstrate the relevance of the pathology to that in man.

\section{Subjects and Methods}

Experimental Animals and AAI Dosage

AAN was induced in 8-week-old C57BL/6 mice by intraperitoneal injection of AAI (Sigma Aldrich, China) using various dosing regimens (table 2). Control animals received intraperitoneal injection of vehicle (DMSO, Sigma Aldrich, China). Mice were maintained at 
Table 2. Dosing regimens tested to induce AAN in C57BL/6 mice

\begin{tabular}{|c|c|c|c|c|}
\hline AAI Dosage & Frequency & Remodelling time & Overall duration & Group (n) \\
\hline $\begin{array}{l}10 \mathrm{mg} / \mathrm{kg} \text { or } \\
20 \mathrm{mg} / \mathrm{kg}\end{array}$ & Single dose & 4 weeks & 4 weeks & $\begin{array}{l}\text { Male control (3) } \\
\text { Male AAN (3) }\end{array}$ \\
\hline $2.5 \mathrm{mg} / \mathrm{kg}$ & $\begin{array}{l}\text { Single dose or once every } \\
2 \text { weeks }\end{array}$ & 4 or 2 weeks & 4 weeks & $\begin{array}{l}\text { Male control (3) } \\
\text { Male AAN (3) }\end{array}$ \\
\hline $2.5 \mathrm{mg} / \mathrm{kg}$ & Once a week for 4 weeks & 1 week & 5 weeks & $\begin{array}{l}\text { Male control (3) } \\
\text { Male AAN (3) }\end{array}$ \\
\hline $2.5 \mathrm{mg} / \mathrm{kg}$ & Once a week for 4 weeks & 4 weeks & 8 weeks & $\begin{array}{l}\text { Male control (3) } \\
\text { Male AAN (3) }\end{array}$ \\
\hline $3 \mathrm{mg} / \mathrm{kg}$ & Once every 3 days for 6 weeks & 6 weeks & 12 weeks & $\begin{array}{l}\text { Male control (5) } \\
\text { Male AAN (5) } \\
\text { Female control (5) } \\
\text { Female AAN (5) }\end{array}$ \\
\hline $3 \mathrm{mg} / \mathrm{kg}$ & Once every 3 days for 3 weeks & 6 weeks & 9 weeks & $\begin{array}{l}\text { Male control (5) } \\
\text { Male AAN (5) }\end{array}$ \\
\hline $3 \mathrm{mg} / \mathrm{kg}$ & Once every 3 days for 6 weeks & 6 weeks & 12 weeks & $\begin{array}{l}\text { Male control (10) } \\
\text { Male AAN (10) }\end{array}$ \\
\hline $3 \mathrm{mg} / \mathrm{kg}$ & Once every 3 days for 6 weeks & 9 weeks & 15 weeks & $\begin{array}{l}\text { Male control (5) } \\
\text { Male AAN (5) }\end{array}$ \\
\hline
\end{tabular}

$20^{\circ} \mathrm{C}$ and $45 \%$ humidity on a 12 -hour light/dark cycle and allowed free access to standard rodent chow and tap water. All procedures were carried out under license according to regulations laid down by Her Majesty's Government, United Kingdom (Animals Scientific Procedures Act, 1986).

\section{Blood Pressure Measurement}

Systolic blood pressure measurement was performed in conscious, restrained mice using a BP-2000 blood pressure analysis system with a tail cuff inflator and a photoelectric sensor (Visitech Systems Inc., USA). To acclimatise the mice, blood pressure measurement was performed 5 days a week for 2 weeks before the actual readings were recorded.

\section{Fibrosis Measurement}

$4 \mu \mathrm{m}$, neutral-buffered, formalin-fixed, paraffin-embedded sections were stained using the Masson's Trichrome stain kit (Sigma Aldrich, UK) following the manufacturer's instructions (stains collagenous material blue and nuclei, fibres, erythrocytes and elastin red/pink). Quantification of kidney fibrosis on Masson's Trichrome-stained sections was undertaken using multiphase image analysis as previously described using Cell F software (Olympus, Germany) [33].

\section{Blood and Urine Chemistry}

Terminal blood samples were taken. Twenty-four-hour urine samples were collected using metabolic cages $24 \mathrm{~h}$ before termination. Serum and urine creatinine were measured as previously described [34] with modifications. $100 \mu \mathrm{l}$ of serum was mixed with $1 \mathrm{ml}$ of acetonitrile or $10 \mu \mathrm{l}$ of urine mixed with $0.5 \mathrm{ml}$ of acetonitrile. Samples were then centrifuged at $13,000 \mathrm{~g}$ for $15 \mathrm{~min}$ at $4^{\circ} \mathrm{C}$. Supernatants were transferred, air dried and resuspended in 50 or $100 \mu \mathrm{l}$ 
of $5 \mathrm{mM}$ sodium acetate ( $\mathrm{pH}$ 5.1) for serum or urine samples, respectively. $25 \mu$ l of processed sample was injected into an Agilent 1100 high-pressure liquid chromatography (HPLC) system with a $10-\mu \mathrm{m} 4.1 \times 100 \mathrm{~mm}$ PRP-X200 cation exchange column (Hamilton, USA). Isocratic HPLC was performed at a flow rate of $1.5 \mathrm{ml} / \mathrm{min}$ for $12 \mathrm{~min}$ after each injection using UV absorbance at $234 \mathrm{~nm}$. A creatinine standard curve between 0 and $0.5 \mathrm{nmol}$ was used for serum and between 0 and $6.5 \mathrm{nmol}$ for urine. Blood urea nitrogen (BUN) was measured by standard autoanalyser technique. Albumin ELISA was performed by using a mouse albumin ELISA kit (Bethyl Laboratories, USA) following the manufacturer's instructions.

\section{Immunofluorescent Staining}

Immunofluorescent staining was carried out on 4 - $\mu$ m paraffin sections using a secondary antibody conjugated with fluorescein isothiocyanate (1:20; DAKO, Denmark) or Texas Red (1:200; Southern Biotech, USA). Following antigen retrieval, primary antibodies were applied as follows: rabbit anti-collagen I (1:100; Abcam, UK), goat anti-collagen (1) III (1:10; Southern Biotech, USA), rabbit anti-collagen IV (1:35; Millipore, USA), rat anti-F4/80 (1:50; Serotec, UK), rat anti-CD45 (1:50; BD Pharmingen, UK), mouse anti- $\alpha$-smooth muscle actin $(\alpha-S M A)$ antibody conjugated with fluorescein isothiocyanate (1:50; Sigma Aldrich, UK), rabbit anti-S100A4 (1:100; Abcam, UK).

\section{Immunofluorescent Collagen Measurements}

Ten cortical fields of each section were acquired at a magnification of 200. These were analysed using multiphase image analysis as above with correction to 4',6-diamidino-2-phenylindole (DAPI) staining.

\section{Hydroxyproline Analysis}

Kidney homogenates containing $1.5 \mathrm{mg}$ protein per sample were hydrolysed in $6 \mathrm{M} \mathrm{HCl}$ at $110^{\circ} \mathrm{C}$ for $18 \mathrm{~h}$. These were clarified by centrifugation at $18,000 \mathrm{~g}$ for $2 \mathrm{~min}$ and freeze dried. Samples were then resuspended in $200 \mu$ l of lithium loading buffer (Biochrom, UK) and $40 \mu \mathrm{l}$ fractionated using a lithium chloride gradient on a Biochrom 30 amino acid analyser using the manufacturer's standard protocol (Biochrom, UK). Hydroxyproline was identified against an amino acid standard and expressed as nmol per mg protein.

\section{Statistical Analysis}

Data is shown as mean \pm SEM. Data analyses were performed using one-way ANOVA or two-way ANOVA followed by a Bonferroni post hoc test. A probability of $95 \%(\mathrm{p}<0.05)$ was taken as significant.

\section{Results}

\section{AAI Dose Optimisation}

A single intraperitoneal dose of $>10 \mathrm{mg} / \mathrm{kg}$ AAI caused acute kidney failure and death within 14 days (fig. 1). Under this regime the tubular cells sloughed off the tubular basement membrane (fig. 1b, arrowhead), with some tubules blocked by debris (fig. 1b, arrow). Single or twin doses (administrated on day 0 and day 14) of $2.5 \mathrm{mg} / \mathrm{kg}$ of AAI failed to induce fibrosis by 1 month (fig. 1c). A weekly injection of $2.5 \mathrm{mg} / \mathrm{kg}$ AAI for 4 weeks plus 1 week disease development time caused tubular damage in the outer cortical area and medullary ray (fig. 1d), with a slight increase in fibrosis when given 4 weeks of disease development time (fig. 1e). A dose of $3 \mathrm{mg} / \mathrm{kg}$ AAI every 3 days for 6 weeks followed by 6 weeks after AAI resulted in more severe tubulointerstitial fibrosis (fig. 1f). 

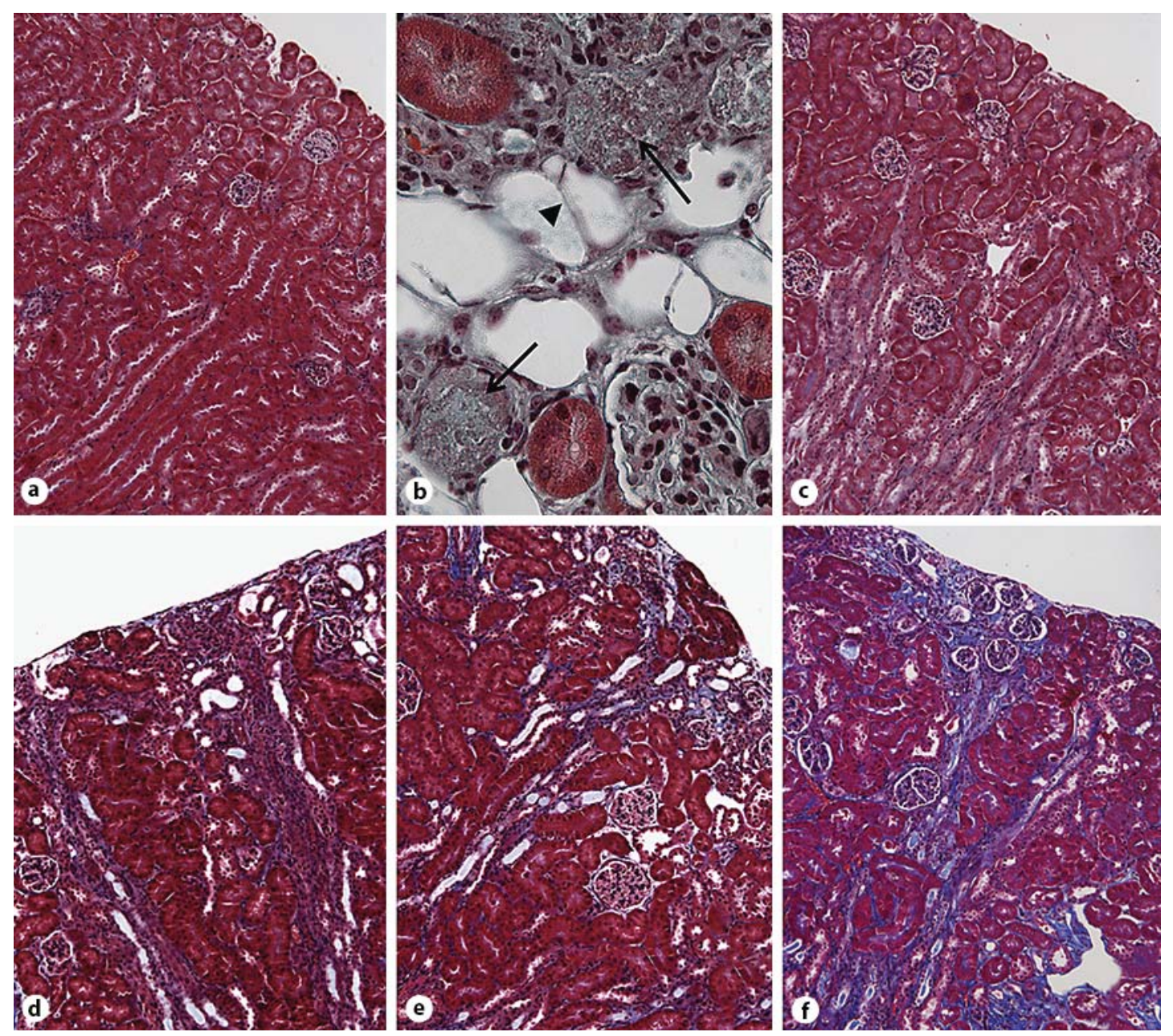

Fig. 1. Masson's Trichrome staining of kidneys from male C57BL/6 mice treated with $\mathrm{AAI}$ at varying dose and frequency. a Control. b $10 \mathrm{mg} / \mathrm{kg}$ single dose ( $\times 400$ magnification). c $2.5 \mathrm{mg} / \mathrm{kg}$ once every 2 weeks for 4 weeks. d $2.5 \mathrm{mg} / \mathrm{kg} /$ week for 4 weeks with 1 week of disease development time. e $2.5 \mathrm{mg} / \mathrm{kg} / \mathrm{week}$ for 4 weeks with 4 weeks of disease development time. $\mathbf{f} 3 \mathrm{mg} / \mathrm{kg}$ once every 3 days for 6 weeks with 6 weeks of disease development time. Magnification is $\times 100$ unless stated.

Although similarly high levels of serum creatinine were detected in mice injected with $2.5 \mathrm{mg} / \mathrm{kg}$ AAI weekly for 4 weeks with 1 week remodelling time and those receiving $3 \mathrm{mg} /$ $\mathrm{kg}$ AAI every 3 days for 6 weeks with 6 weeks remodelling time (fig. 2), the first group failed to develop corresponding fibrosis (fig. 1d, f). Therefore, the dose of $3 \mathrm{mg} / \mathrm{kg}$ AAI every 3 days for 6 weeks was chosen for further studies in both male and female C57BL/6 mice.

\section{General Observation - 12-Week Model}

Five male and 5 female mice received either $3 \mathrm{mg} / \mathrm{kg}$ AAI every 3 days (AAN groups) or vehicle (control groups) for 6 weeks and were then left for another 6 weeks. Mice not receiving AAI showed a steady increase in body weight through the experimental period. Compared to the untreated mice, mice receiving AAI had 30.7 and $15.2 \%$ weight loss in male and female animals, respectively, at 12 weeks (fig. 3a). There was a small trend of increased systolic blood pressure in AAN mice (fig. 4a). However, the change was not significant. Kidneys from AAN animals were all found to be smaller and paler (fig. 3b). $90 \%$ of the AAN mice 
Fig. 2. Kidney function in male C57BL/6 mice treated with AAI at varying dose and frequency. Kidney function was assessed by measuring serum creatinine concentrations $(\mu \mathrm{M})$ in mice treated with different doses of AAI (the $\mathrm{x}$-axis labels show AAI concentration used per injection with number of injections given and overall duration in brackets). Data represent mean \pm SEM; $\mathrm{n}=3-5$ per group. * Indicates statistical significance compared to the control group.

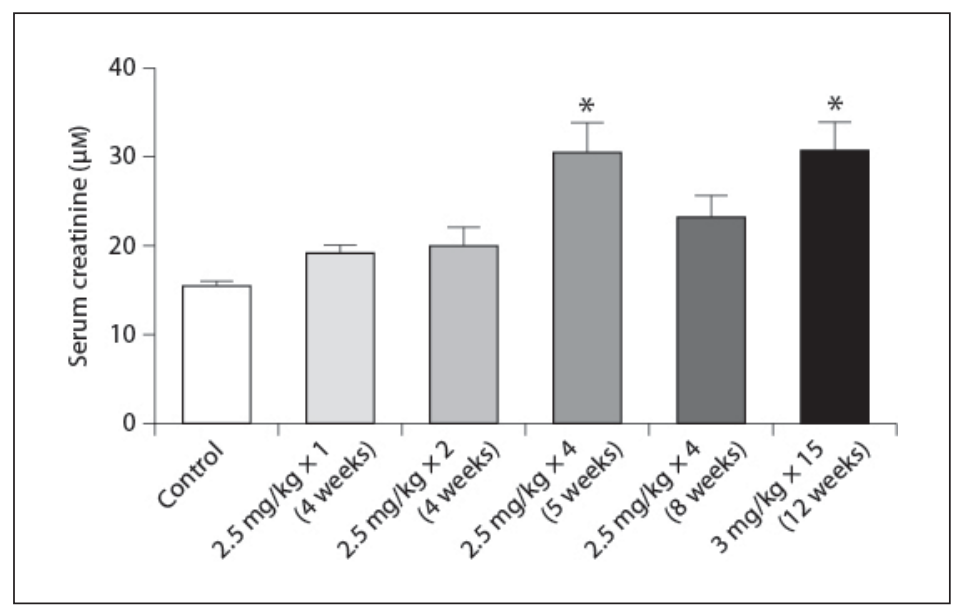

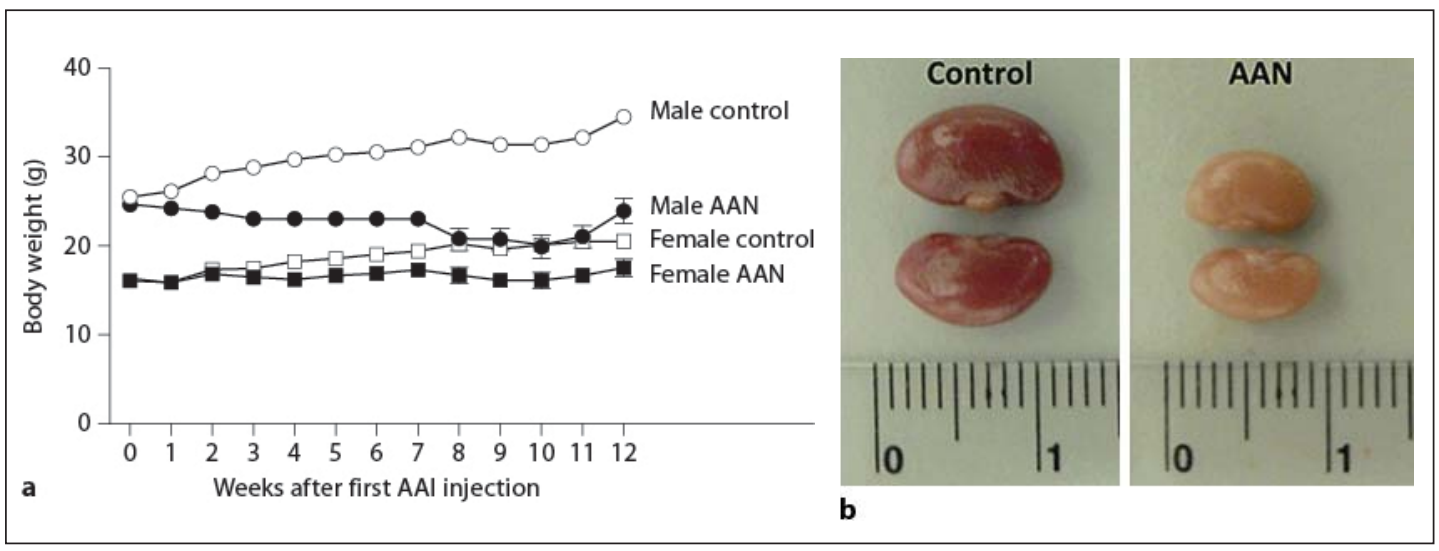

Fig. 3. Body weight and kidney size in control and AAN mice. Mice were treated with $3 \mathrm{mg} / \mathrm{kg}$ of AAI for 6 weeks and then maintained for further 6 weeks. Mouse body weight was measured at least once a week throughout the 12 weeks (a). Kidneys were removed at termination and directly compared. Male kidneys are shown (b). Data represent mean $\pm \mathrm{SEM} ; \mathrm{n}=5$ per group.

also showed smaller and paler livers. There was no obvious tumour development observed in organs, but $50 \%$ of AAN mice did start to develop observable ascites 5 weeks after the first AAI injection.

\section{Kidney Weight and Function}

Mice receiving AAI had a $60.8 \%$ loss of kidney weight in males and $36 \%$ in females (fig. 4b). AAI caused increases in serum creatinine from 15.4 to $34.4 \mu \mathrm{M}$ in male mice and from 8.6 to $21.9 \mu \mathrm{M}$ in female mice (fig. 4c). Changes in BUN were consistent with changes in serum creatinine (fig. $4 \mathrm{~d}$ ).

\section{Kidney Fibrosis}

The lesions in the AAN kidney from C57BL/6 mice were mainly located in the cortical area, especially at the edge of the cortex and medullary ray. The damage to the tubules caused by AAI seemed to be identical in both male (fig. 5b) and female (fig. $5 \mathrm{~d}$ ) mice. However, the subsequent tubulointerstitial fibrosis was more severe in male AAN mice than in female AAN mice (fig. 6a). This was confirmed by levels of hydroxyproline (representing whole kid- 


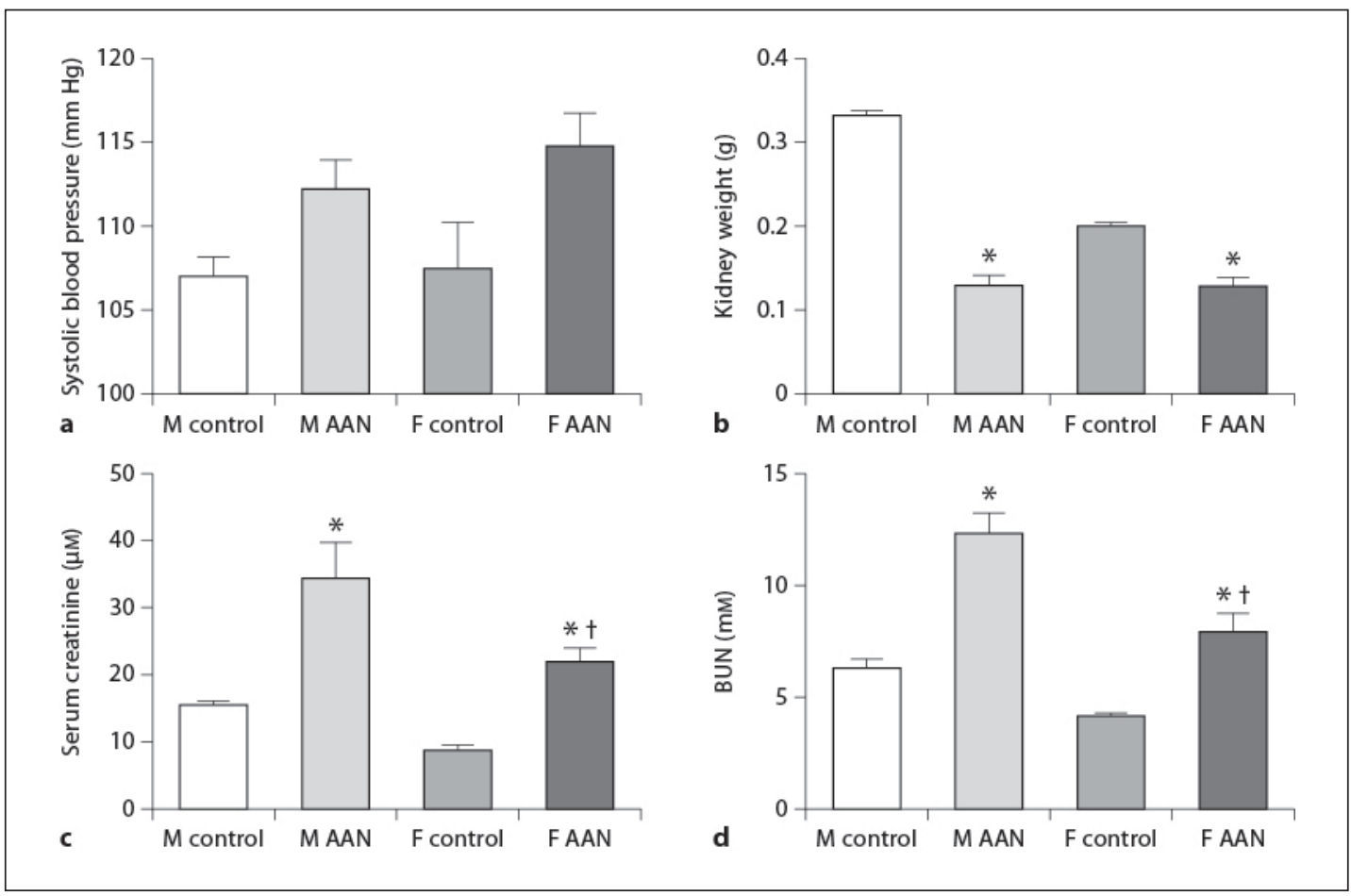

Fig. 4. Systolic blood pressure, kidney weight and function differences in male and female mice. Male (M) and female (F) mice were treated with $3 \mathrm{mg} / \mathrm{kg}$ of AAI for 6 weeks and then maintained for a further 6 weeks. Systolic blood pressure measurement was performed using a BP-2000 blood pressure analysis system (a). Kidneys were removed at termination and weighed (b). Kidney function was measured by serum creatinine (c) and BUN (d). Data represent mean \pm SEM; $n=5$ per group. ${ }^{*}$ Indicates statistical significance compared to the control group. ${ }^{\dagger}$ Indicates statistical significance compared to male AAN mice.

ney collagen). In the AAN male mice, levels of hydroxyproline were 4.7 times higher than in the male control group, while in female mice, it was reduced to 2.1-fold between AAN and control animals (fig. 6b). While there were clearly pockets of hypocellular fibrosis (fig 5b), especially in the medullary rays, the majority of the lesions contained increased numbers of infiltrating cells, notably in the outer cortex of the AAN kidneys. The bulk of the infiltrating cells were CD45+ lymphocytes (fig. 7A), although there were significant numbers of fibroblast specific protein 1 (FSP1) positive cells present in the AAN kidney. However, most of these were not $\alpha$-SMA positive (fig 7B). The $\alpha$-SMA positive cells in the AAN kidney were mainly vascular smooth muscle cells seen in arteries and arterioles (fig. 7B). Macrophages were hardly detectable (fig. 7C).

\section{Specific Collagen Accumulation}

Increased collagen I was observed in the tubulointerstitial area in both male (fig. $5 \mathrm{f}$ ) and female (fig. 5h) AAN mice (fig. 6c). Changes in collagen III showed a similar trend to collagen I, with higher levels of collagen III deposition in the tubulointerstitium in male AAN mice than female AAN mice (fig. 6d). Kidneys from male AAN mice clearly demonstrated an elevated deposition of collagen IV occurred in the tubulointerstitium near the edge of the cortex and around the glomerular capsule (fig. 5n). Although there was a trend towards increasing collagen IV in female AAN mice, this was not significant. Again changes in collagen IV deposition were higher in male AAN than in female AAN mice (fig. 6e). 


\section{nephron}
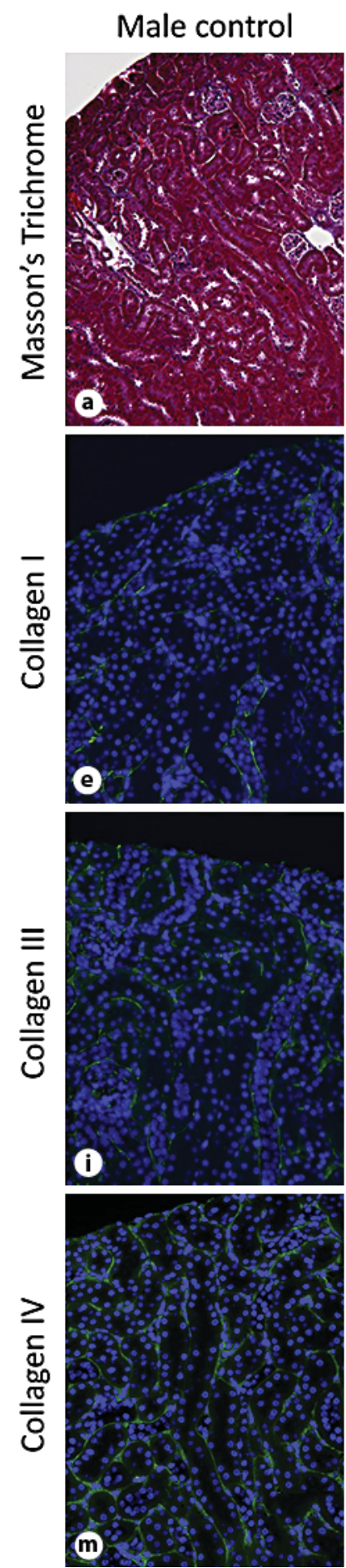

Nephron Extra 2013;3:12-29

DOI: $10.1159 / 000346180$

Published online: January 11, 2013

(c) 2013 S. Karger AG, Base

www.karger.com/nne

Huang et al.: Development of a Chronic Kidney Disease Model in C57BL/6 Mice with

Relevance to Human Pathology
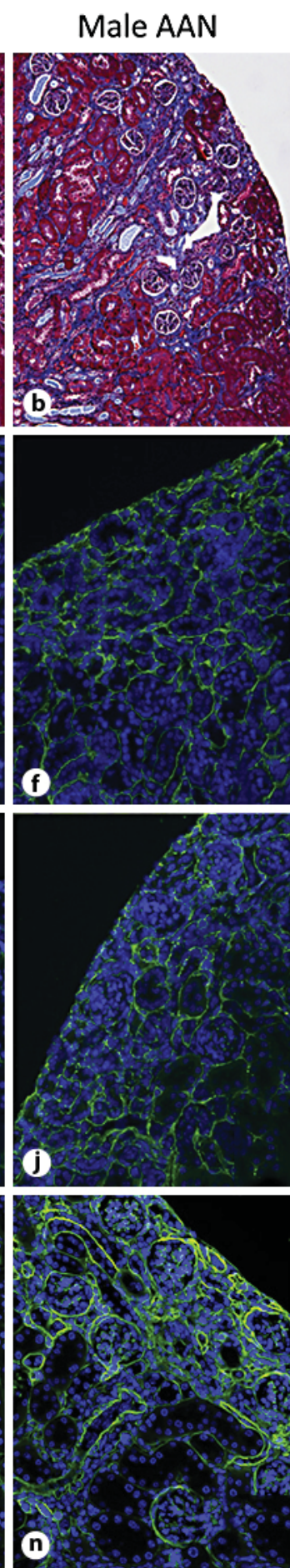

(
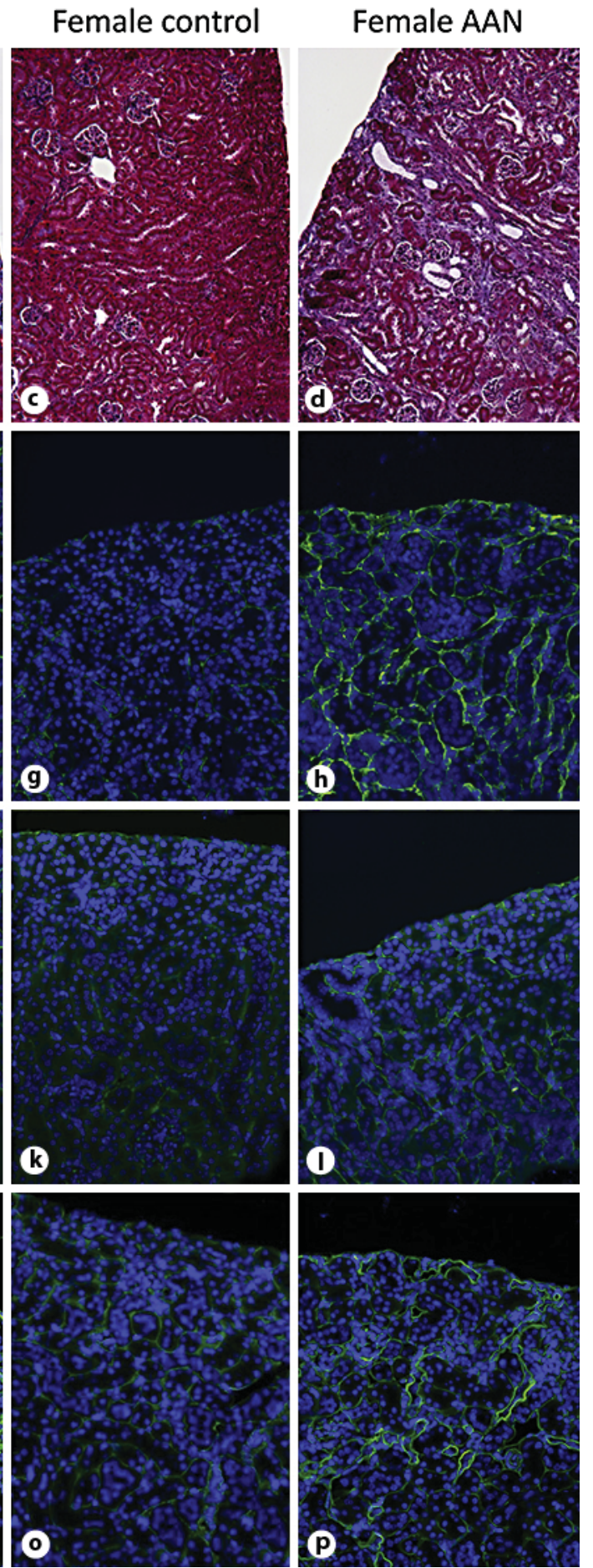

Fig. 5. Masson's Trichrome $(\times 100)$ and immunofluorescent staining of collagens $(\times 200)$. Male (left hand columns) and female (right hand columns) mice were treated with $3 \mathrm{mg} / \mathrm{kg}$ of AAI for 6 weeks and then maintained for a further 6 weeks. Paraffin sections were stained with Masson's Trichrome $(\mathbf{a}-\mathbf{d})$, collagen I (e-h), collagen III (i-I) and collagen IV $(\mathbf{m}-\mathbf{p})$. Nuclei were stained with DAPI. 


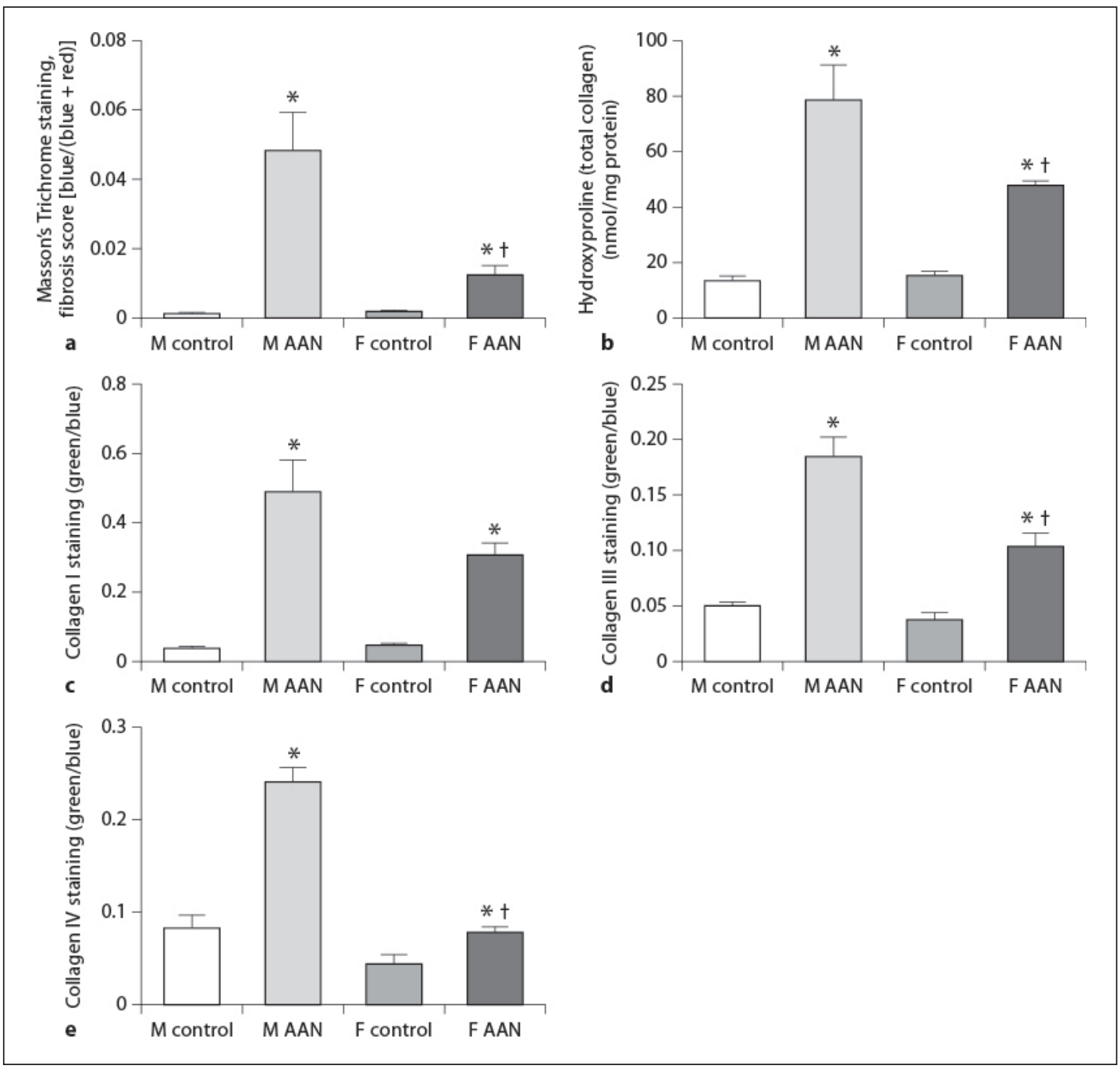

Fig. 6. Comparison of fibrosis levels and collagen I, III and IV immunostaining between male and female C57BL/6 mice. Male (M) and female (F) mice were treated with $3 \mathrm{mg} / \mathrm{kg}$ of AAI for 6 weeks and then maintained for a further 6 weeks. Masson's Trichrome staining (a) and immunofluorescence for collagen I (c), collagen III (d) and collagen IV (e) shown in figure 5 were quantified by multiphase image analysis of 10 fields per section. Kidney hydroxyproline in the same mice was expressed as nmol per mg protein (b). Data represent mean \pm SEM; $n=5$ per group. ${ }^{*}$ Indicates statistical significance compared to the control group. ${ }^{\dagger}$ Indicates statistical significance compared to male AAN mice.

Correlation analysis between Masson's Trichrome staining and the three stained collagens revealed that increases in the deposition of collagen I (Pearson's $r=0.7221, p=0.0003$ ), collagen III (Pearson's $r=0.8501, \mathrm{p}<0.0001$ ) and collagen IV (Pearson's $r=0.7928, \mathrm{p}<$ $0.0001)$ contributed to the build-up of fibrosis.

\section{Disease Progression}

To assess if progressive disease could be established in the AAN model, a repeat experiment was performed. From the 12-week model used above (6 weeks AAI treatment with 6 weeks remodelling time) experimental periods were shortened to 9 weeks with the AAI treatment time reduced to 3 weeks, or lengthened by keeping to 6 weeks of AAI treatment and al- 
Fig. 7. Immunofluorescent staining of infiltrating inflammatory cells and fibroblasts in the AAN kidney. $4 \mu \mathrm{m}$ thick sections from 12-week-old male AAN mice were stained with CD45 (A), S100A4 in red and $\alpha$-SMA in green (B), and F4/80 (C). Nuclei were stained with DAPI. Boxed area on $\times 200$ image is shown at $\times 400$ magnification in the right column.

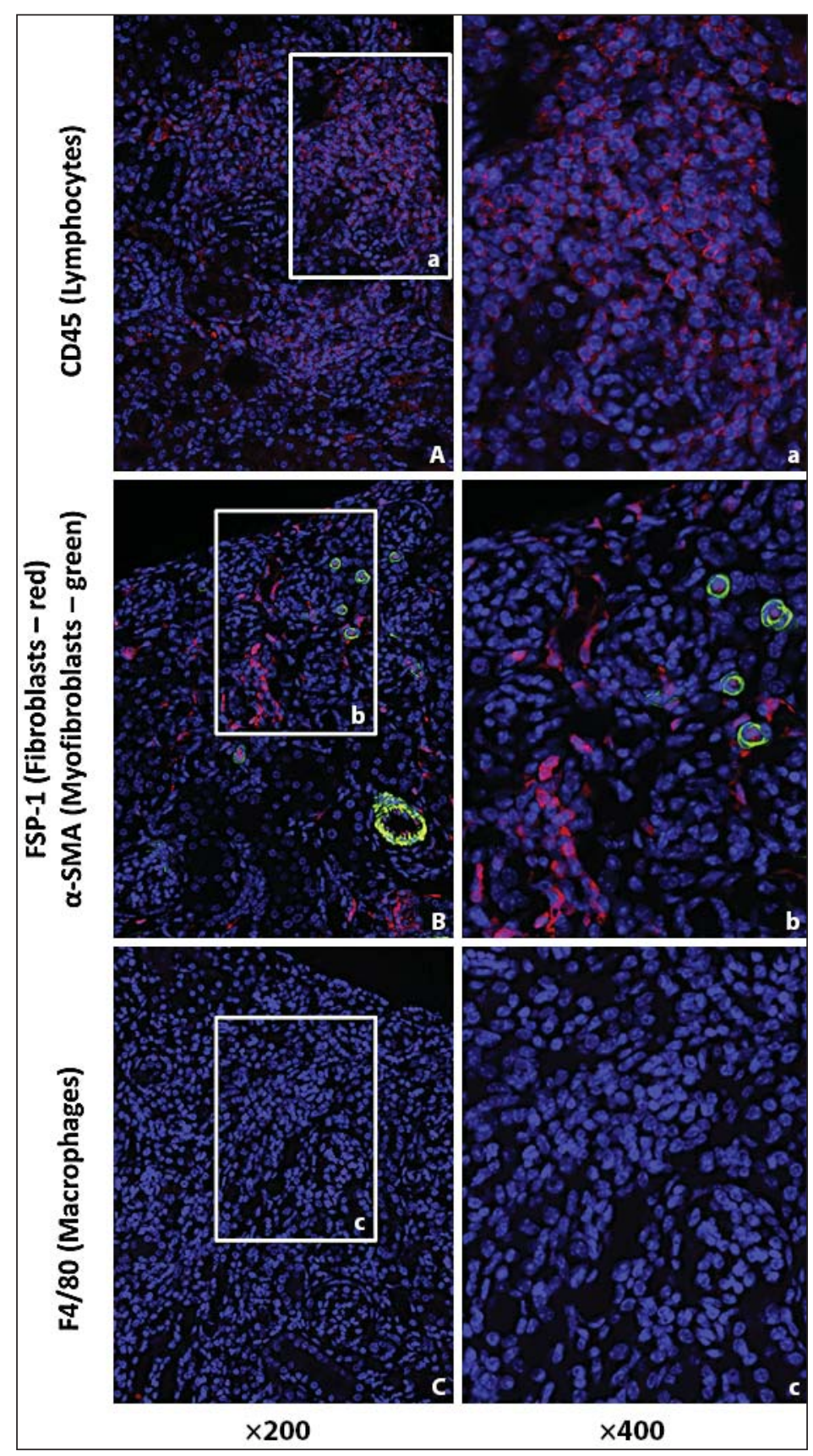

lowing 9 weeks after cessation of AAI (i.e. 15 weeks) (table 2). No significant changes in blood pressure were detected between the AAI-treated and AAI-untreated animals along the experimental period (data not shown). Results of both serum creatinine (fig. 8a) and creatinine clearance (fig. 8b) showed that kidney function was impaired by 9 weeks, but given a longer disease development time, it started to recover progressively from 9 to 15 weeks when the difference no longer reached significance. Although the albumin/creatinine ratio in urine was increased in the AAN mice, it only reached significance at 12 weeks (fig. 8c). Kidney fibrosis as demonstrated by Masson's Trichrome staining showed that the damage occurred around the outer cortex area by 9 weeks (fig. 9a) and collagen accumulation (blue) was increased by 12 weeks (fig. 9b) and progressed to 15 weeks (fig. 9c). This was confirmed by quantification 


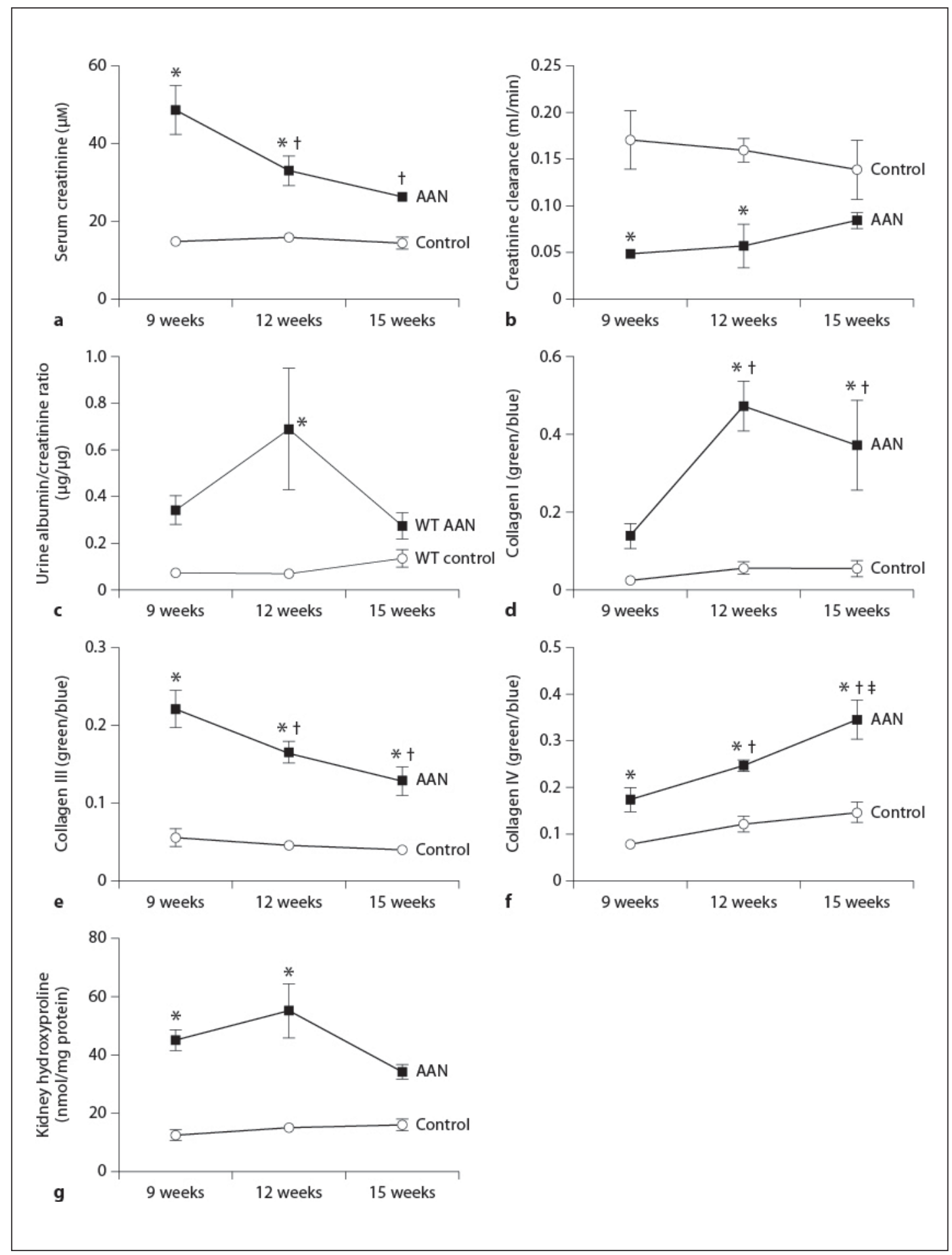

Fig. 8. Comparison of kidney function, levels of collagen I, III and IV immunostaining and hydroxyproline in male mice with progression of AAN. Kidney function in the mice described in figure 7 was assessed using serum creatinine (a), creatinine clearance (b) and urine albumin/creatinine ratio (c). Quantification of immunofluorescence for collagen I (d), collagen III (e) and collagen IV (f) in the kidney were assessed by multiphase image analysis of 10 fields per section. Levels of hydroxyproline were expressed as nmol per mg protein $(\mathbf{g})$. Data represent mean \pm SEM; $n=5-10$ per group. ${ }^{*}$ Indicates statistical significance compared to the control group. ${ }^{\dagger}$ and ${ }^{\ddagger}$ indicate changes from 9 and 12 weeks AAN groups, respectively. 

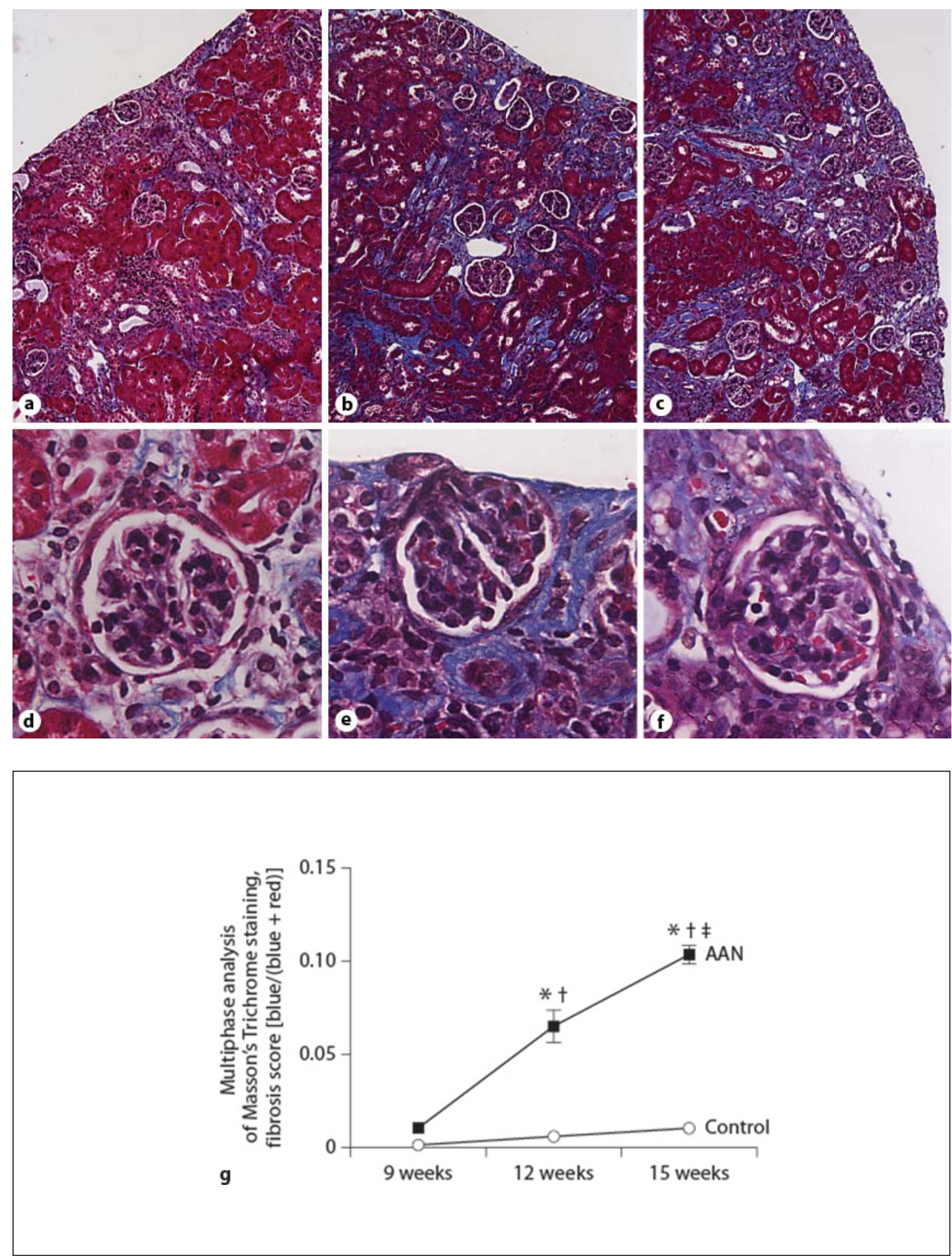

Fig. 9. Masson's Trichrome staining in male mice with the progression of AAN. Male mice were treated with either AAI for 3 weeks followed by 6 weeks remodelling time ( 9 weeks), AAI for 6 weeks followed by 6 weeks remodelling time (12 weeks) or AAI for 6 weeks followed by 9 weeks remodelling time ( 15 weeks). The development of kidney fibrosis is shown by Masson's Trichrome-stained slides (a-f). Quantification of Masson's Trichrome staining $(\mathbf{g})$ was assessed by multiphase image analysis of 10 fields per section. Data represent mean \pm SEM; $n=5-10$ per group. ${ }^{*}$ Indicates statistical significance compared to the control group. ${ }^{\dagger}$ and ${ }^{\ddagger}$ indicate changes from 9 and 12 weeks AAN groups, respectively. 


\section{nephron}

\begin{tabular}{l|l}
\hline Nephron Extra 2013;3:12-29 \\
\hline DOI: 10.1159/000346180 & $\begin{array}{l}\text { @ 2013 S. Karger AG, Basel } \\
\text { www.karger.com/nne }\end{array}$ \\
\hline Published online: January 11, 2013 &
\end{tabular}

Huang et al.: Development of a Chronic Kidney Disease Model in C57BL/6 Mice with Relevance to Human Pathology
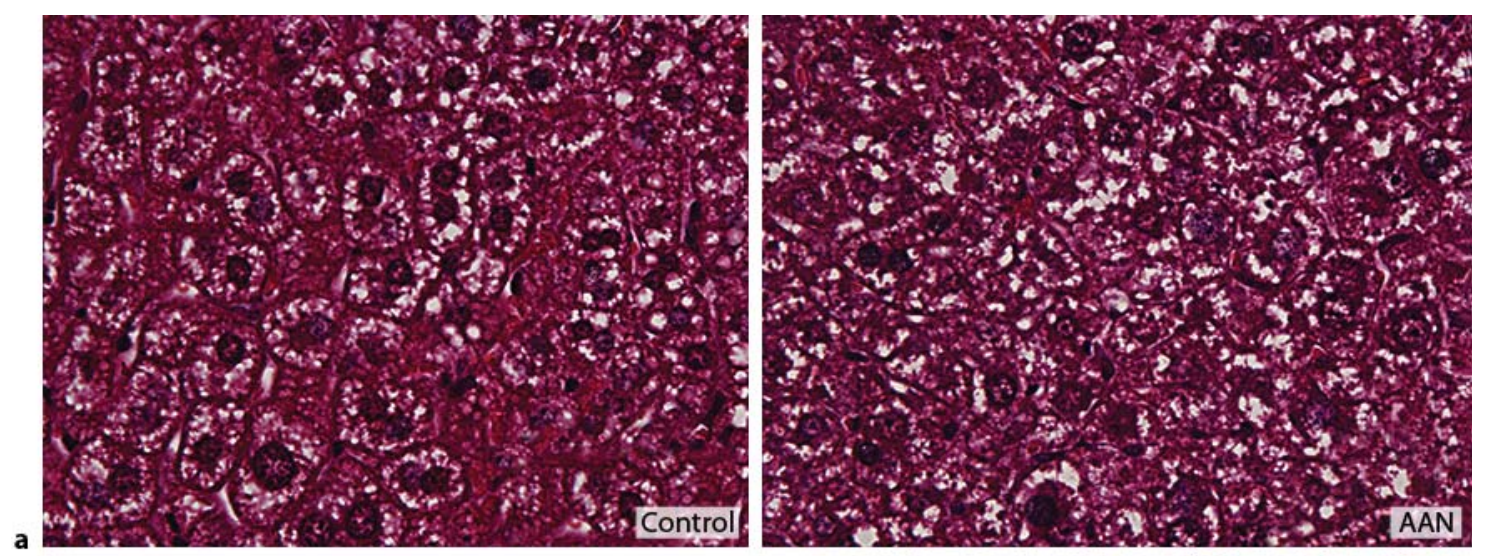

a
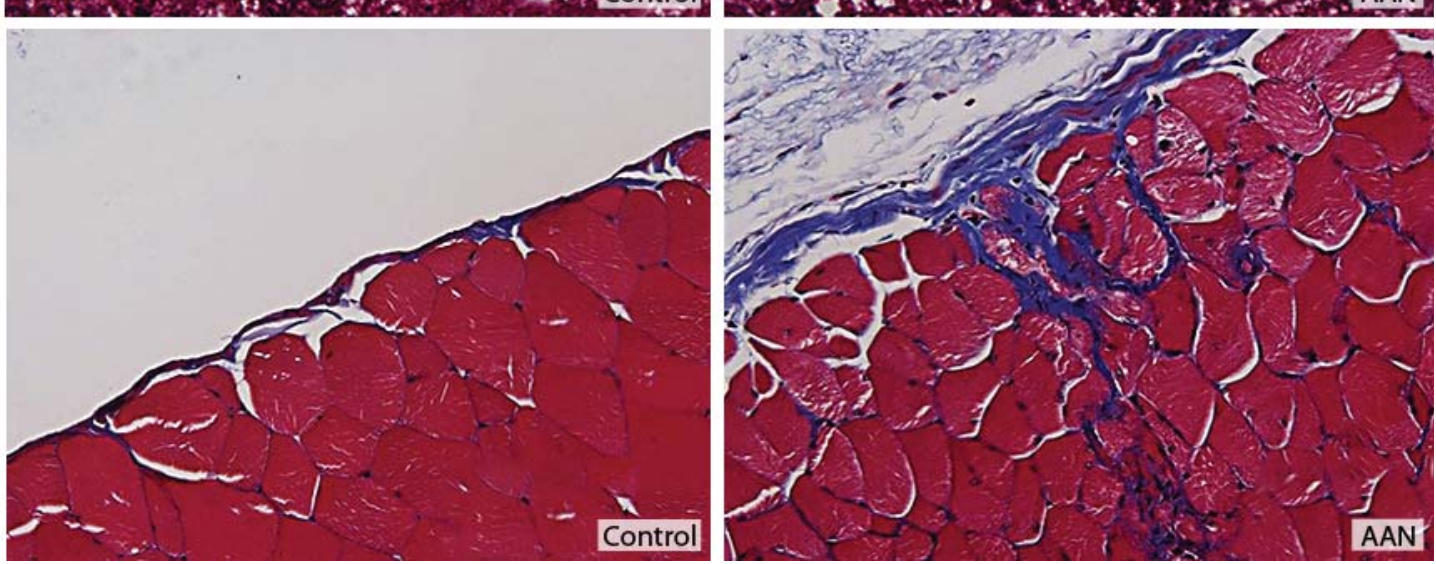

Fig. 10. Masson's Trichrome staining of liver (a) and peritoneum (b). $4 \mu \mathrm{m}$ thick sections from 12 -weekold male mice treated with AA1 were stained with Masson's Trichrome ( $\times 400$ magnification).

of the staining (fig. 9g). However, no obvious fibrotic changes were observed in glomeruli (fig. 9d, e). Significant increases in collagen I deposition occurred at 12 and 15 weeks (fig. 8d). Levels of collagen III deposition were increased in the AAN groups at the 3 time points, but they started to decrease from 12 weeks (fig. 8e). In contrast, collagen IV accumulation in the AAN groups was progressively increased throughout the experimental period (fig. 8f). When whole kidney collagen levels were assessed, in AAN mice an increase of kidney collagen was seen at 9 and 12 weeks until no significant difference was noted at 15 weeks (fig. 8g).

\section{Discussion}

To date, a large number of studies have used genetically modified mice on a C57BL/6 background to demonstrate the role of specific genes in the progression of various diseases. However, C57BL/6 mice have been reported to be the most nephropathy-resistant strain, limiting the extent of their use in CKD studies $[8,29,35]$. Therefore, to address this we have established a suitable AAN model of CKD in this strain of mice.

The regimen of a $3 \mathrm{mg} / \mathrm{kg}$ AAI intraperitoneal injection once every 3 days for 6 weeks with 6 weeks remodelling time was selected for more substantial analysis as reduced kidney function was accompanied by clear tubulointerstitial fibrosis in the outer cortical area including the medullary ray. Hypocellular scarring is a typical human AAN feature, but was clearly not as prominent in this model being restricted to the lower areas of the medullary 
ray. Instead, the bulk of the fibrosis was associated with both a lymphocyte and fibroblast interstitial infiltrate. However, it should be noted that in man, there are also pockets of fibrosis with interstitial infiltrate present amongst the hypocellular fibrosis within the published images [17] which are often disregarded. Importantly, in this 12-week mouse model, lesions in the C56BL/6 kidney matched the detailed AAN pattern reported in rabbit [11] and in man [17] with progression down the medullary rays and sparing of the glomeruli. Of note was that there were clearly FSP-1-positive fibroblasts detectable in the interstitium which were not $\alpha$ SMA positive and thus unlikely to be myofibroblasts. $\alpha$-SMA staining was not noted outside of the vasculature at any of the 3 time points studied and thus it is not likely, but cannot be proved because of remodelling times used, that the extracellular matrix (ECM) expansion is myofibroblast independent. While it is recognised that tubular cells can drive ECM expansion in AAN by the production of interstitial collagens [36], fibroblasts would clearly contribute to scar tissue formation by increasing interstitial collagen production and components which regulate the ECM homeostasis such as TIMPs and MMPs.

The increase in infiltrating cells in the AAN mice kidney is consistent with a rat AAN model where Pozdzik et al. [37] demonstrated that during the progression of AAN, there was an early and massive interstitial inflammation consisting of monocytes, macrophages and $\mathrm{T}$ lymphocytes, explaining why steroid therapy is also beneficial in some AAN patients at earlier stages of disease [38].

A potential complication of this model is the development of ascites, which was surprising given that this has not previously been reported in AAN models. However, given that some of the models described in table 1 used much higher doses of AA and often for a prolonged period, it is difficult to understand why this had not been described before. Although there was no liver cirrhosis visible in any animal when assessed using Masson's Trichrome staining, and the morphology looked normal in all animals (fig. 10a), livers from $90 \%$ of the AAN animals did seem to be slightly paler and fractionally smaller suggesting liver damage may potentially contribute to the ascites seen in the AA-treated animals. Alternatively, ascites could be the consequence of peritoneum mesothelioma, consistent with the carcinogenic potential of AAI. Although specific AA-DNA adducts were not found in the peritoneum from AAN patient, such typical biomarkers of genotoxic damage by AA were present in the rabbit peritoneum which had been directly exposed to AA by intraperitoneal injection [39]. No mesotheliomas were seen in this study, although Masson's Trichrome staining on the peritoneum confirmed that some peritoneal sclerosis occurred in AAN mice (fig. 10b), which may also cause ascites, as could AAI-induced inflammation in the peritoneum that causes inflammatory ascites. Irrespective, the cause of ascites induced by AAI is beyond the scope of this study, but effectively limits AAI administration at $3 \mathrm{mg} / \mathrm{kg}$ every 3 days to 6 weeks duration as beyond this, drainage may be needed in some mice, while the 9-week model with 3 weeks of AA1 treatment is less problematic in terms of ascites.

Of interest, the AAN mice showed an obvious gender difference in disease progression. As in humans, males typically had a faster progression to ESKF [40-43]. The female sex hormone oestrogen is reported to contribute to the renal protective effect by interacting with endogenous vasoactive mediators such as endothelial nitric oxide synthase (eNOS) and vascular endothelial growth factor (VEGF) [44]. Equally, testosterone has been shown to have an effect on kidney morphology. Male rats have a larger cortex due to a more extensive development of proximal tubules. Female rats have a greater volume of the medulla, gaining an increased proximal tubule volume if treated with testosterone [45]. Therefore, due to AA damaging mainly the cortical region by targeting proximal tubules, it is not surprising that the application of AAI has more severe consequences in male mice. That said, in Europe AAN predominantly affects the female gender. This may be explained by the fact that women are more likely to attend slimming programmes [46]. 
Of note in this study is that when fibrosis is measured by the area of Masson's Trichrome and collagen immunofluorescence, it continues to increase from 9 to 15 weeks based on area of positive stain. In contrast, levels of total kidney collagen (hydroxyproline) adopt a downward trend at 15 weeks, while kidney function also appears to recover. It is noticeable that while the area of lesions increases, the intensity by eye of Masson's Trichrome staining lowers, which is indicative of lower ECM levels. This is supported by the hydroxyproline data which would also measure increased collagen synthesis at the time of insult as well as that deposited. Therefore, we predict that given time, the mice would undergo remission as occurs in about $30 \%$ of human AAN patients who are identified early. Thus, we hypothesise that if this accelerated model is to be pushed into ESKF, a second period of AAI injections is needed to facilitate irreversible CKD in much the same way that is used in nephrotoxic nephritis models of CKD. Given that some animals develop ascites after 5 weeks of treatment at $3 \mathrm{mg} / \mathrm{kg}$ every 3 days, we suggest that a 3 -week AAI administration period with 6 weeks of recovery followed by a second 3-week AAI administration period may facilitate ESKF without the complication of ascites. However, the potential start of recovery in the model described here between 12 and 15 weeks provides the opportunity to study mechanisms involved in fibrosis resolution or remission which are also of great scientific value.

The model described here is simple, reproducible, independent of variations in AA, provides functional data, can be used in mice and is technically undemanding without the need for surgical skill or facilities. It effectively can be used as a generic model of interstitial fibrosis in much the same way as the subtotal nephrectomy and UUO models are currently used, but has characteristics of many types of interstitial nephropathies, for example ischemia, Lupus nephritis, partial ureteric obstruction, analgesic nephropathy and tubular toxicity. In conclusion, we have shown that AAN can be induced in C57BL/6 mice with a similar pathology to human disease. Unlike previous studies, the regimen chosen was capable of inducing substantial tubulointerstitial fibrosis in a compressed time frame rather than acute kidney failure seen with a high single dose. It is anticipated that this model of experimental kidney fibrosis could be consistently induced in genetically modified mice with a C57BL/6 background, thus offering a valid alternative to the well-established UUO model with the benefit of kidney function measurements and fibrotic lesions more closely reflecting those in man.

\section{Acknowledgements}

This work has been supported by Wellcome Trust grant 087163 to T.S.J. and E.A.M.V., and the Sheffield Kidney Research Foundation.

\section{Disclosure Statement}

The authors declare that they have no conflicts of interest.

\section{References}

$\checkmark 1$ Cole J, Quach DL, Sundaram K, Corvol P, Capecchi MR, Bernstein KE: Mice lacking endothelial angiotensin-converting enzyme have a normal blood pressure. Circ Res 2002;90:87-92.

-2 Pacholczyk G, Suhag R, Mazurek M, Dederscheck SM, Koni PA: Generation of C57BL/6 knockout mice using $\mathrm{C} 3 \mathrm{H} \times \mathrm{BALB} / \mathrm{c}$ blastocysts. Biotechniques 2008;44:413-416. 
-3 Seong E, Saunders TL, Stewart CL, Burmeister M: To knockout in 129 or in C57BL/6: that is the question. Trends Genet 2004;20:59-62.

-4 Eddy AA, Lopez-Guisa JM, Okamura DM, Yamaguchi I: Investigating mechanisms of chronic kidney disease in mouse models. Pediatr Nephrol 2012;27:1233-1247.

-5 Vielhauer V, Anders HJ, Mack M, Cihak J, Strutz F, Stangassinger M, Luckow B, Grone HJ, Schlondorff D: Obstructive nephropathy in the mouse: progressive fibrosis correlates with tubulointerstitial chemokine expression and accumulation of CC chemokine receptor 2- and 5-positive leukocytes. J Am Soc Nephrol 2001;12:1173-1187.

-6 Tesch GH, Lim AK: Recent insights into diabetic renal injury from the $\mathrm{db} / \mathrm{db}$ mouse model of type 2 diabetic nephropathy. Am J Physiol Renal Physiol 2011;300:F301-F310.

7 Kren S, Hostetter TH: The course of the remnant kidney model in mice. Kidney Int 1999;56:333-337.

8 Ma LJ, Fogo AB: Model of robust induction of glomerulosclerosis in mice: importance of genetic background. Kidney Int 2003;64:350-355.

-9 Ishola DA Jr, van der Giezen DM, Hahnel B, Goldschmeding R, Kriz W, Koomans HA, Joles JA: In mice, proteinuria and renal inflammatory responses to albumin overload are strain-dependent. Nephrol Dial Transplant 2006;21:591-597.

10 Vanherweghem JL, Depierreux M, Tielemans C, Abramowicz D, Dratwa M, Jadoul M, Richard C, Vandervelde D, Verbeelen D, Vanhaelen-Fastre R, et al: Rapidly progressive interstitial renal fibrosis in young women: association with slimming regimen including Chinese herbs. Lancet 1993;341:387-391.

-11 Cosyns JP, Dehoux JP, Guiot Y, Goebbels RM, Robert A, Bernard AM, van Ypersele de Strihou C: Chronic aristolochic acid toxicity in rabbits: a model of Chinese herbs nephropathy? Kidney Int 2001; 59:2164-2173.

-12 Debelle FD, Nortier JL, De Prez EG, Garbar CH, Vienne AR, Salmon IJ, Deschodt-Lanckman MM, Vanherweghem JL: Aristolochic acids induce chronic renal failure with interstitial fibrosis in saltdepleted rats. J Am Soc Nephrol 2002;13:431-436.

-13 Martinez MC, Nortier J, Vereerstraeten P, Vanherweghem JL: Progression rate of Chinese herb nephropathy: impact of Aristolochia fangchi ingested dose. Nephrol Dial Transplant 2002;17:408-412.

-14 Nortier JL, Martinez MC, Schmeiser HH, Arlt VM, Bieler CA, Petein M, Depierreux MF, De Pauw L, Abramowicz D, Vereerstraeten P, Vanherweghem JL: Urothelial carcinoma associated with the use of a Chinese herb (Aristolochia fangchi). N Engl J Med 2000;342:1686-1692.

-15 Schmeiser HH, Bieler CA, Wiessler M, van Ypersele de Strihou C, Cosyns JP: Detection of DNA adducts formed by aristolochic acid in renal tissue from patients with Chinese herbs nephropathy. Cancer Res 1996;56:2025-2028.

- 16 Vanhaelen M, Vanhaelen-Fastre R, But P, Vanherweghem JL: Identification of aristolochic acid in Chinese herbs. Lancet 1994;343:174.

-17 Cosyns JP, Jadoul M, Squifflet JP, De Plaen JF, Ferluga D, van Ypersele de Strihou C: Chinese herbs nephropathy: a clue to Balkan endemic nephropathy? Kidney Int 1994;45:1680-1688.

-18 Reginster F, Jadoul M, van Ypersele de Strihou C: Chinese herbs nephropathy presentation, natural history and fate after transplantation. Nephrol Dial Transplant 1997;12:81-86.

- 19 Kabanda A, Jadoul M, Lauwerys R, Bernard A, van Ypersele de Strihou C: Low molecular weight proteinuria in Chinese herbs nephropathy. Kidney Int 1995;48:1571-1576.

-20 Nortier JL, Deschodt-Lanckman MM, Simon S, Thielemans NO, de Prez EG, Depierreux MF, Tielemans CL, Richard C, Lauwerys RR, Bernard AM, Vanherweghem JL: Proximal tubular injury in Chinese herbs nephropathy: monitoring by neutral endopeptidase enzymuria. Kidney Int 1997;51: 288-293.

-21 van Ypersele de Strihou C, Vanherweghem JL: The tragic paradigm of Chinese herbs nephropathy. Nephrol Dial Transplant 1995;10:157-160.

22 Vanherweghem LJ: Misuse of herbal remedies: the case of an outbreak of terminal renal failure in Belgium (Chinese herbs nephropathy). J Altern Complement Med 1998;4:9-13.

-23 Sun D, Feng J, Dai C, Sun L, Jin T, Ma J, Wang L: Role of peritubular capillary loss and hypoxia in progressive tubulointerstitial fibrosis in a rat model of aristolochic acid nephropathy. Am J Nephrol 2006;26:363-371.

-24 Yang L, Li X, Wang H: Possible mechanisms explaining the tendency towards interstitial fibrosis in aristolochic acid-induced acute tubular necrosis. Nephrol Dial Transplant 2007;22:445-456.

-25 Shibutani S, Dong H, Suzuki N, Ueda S, Miller F, Grollman AP: Selective toxicity of aristolochic acids I and II. Drug Metab Dispos 2007;35:1217-1222. 
-26 Arlt VM, Alunni-Perret V, Quatrehomme G, Ohayon P, Albano L, Gaid H, Michiels JF, Meyrier A, Cassuto E, Wiessler M, Schmeiser HH, Cosyns JP: Aristolochic acid (AA)-DNA adduct as marker of AA exposure and risk factor for AA nephropathy-associated cancer. Int J Cancer 2004;111:977-980.

-27 Mengs U: Acute toxicity of aristolochic acid in rodents. Arch Toxicol 1987;59:328-331.

- 28 Okada H, Watanabe Y, Inoue T, Kobayashi T, Kanno Y, Shiota G, Nakamura T, Sugaya T, Fukamizu A, Suzuki H: Transgene-derived hepatocyte growth factor attenuates reactive renal fibrosis in aristolochic acid nephrotoxicity. Nephrol Dial Transplant 2003;18:2515-2523.

- 29 Sato N, Takahashi D, Chen SM, Tsuchiya R, Mukoyama T, Yamagata S, Ogawa M, Yoshida M, Kondo S, Satoh N, Ueda S: Acute nephrotoxicity of aristolochic acids in mice. J Pharm Pharmacol 2004;56: 221-229.

-30 Xiao Y, Ge M, Xue X, Wang C, Wang H, Wu X, Li L, Liu L, Qi X, Zhang Y, Li Y, Luo H, Xie T, Gu J, Ren J: Hepatic cytochrome P450s metabolize aristolochic acid and reduce its kidney toxicity. Kidney Int 2008;73:1231-1239.

-31 Xue X, Xiao Y, Zhu H, Wang H, Liu Y, Xie T, Ren J: Induction of P450 1A by 3-methylcholanthrene protects mice from aristolochic acid-I-induced acute renal injury. Nephrol Dial Transplant 2008;23: 3074-3081.

-32 Zhou L, Fu P, Huang XR, Liu F, Chung AC, Lai KN, Lan HY: Mechanism of chronic aristolochic acid nephropathy: role of Smad3. Am J Physiol Renal Physiol 2010;298:F1006-F1017.

- 33 Huang L, Haylor JL, Hau Z, Jones RA, Vickers ME, Wagner B, Griffin M, Saint RE, Coutts IG, El Nahas AM, Johnson TS: Transglutaminase inhibition ameliorates experimental diabetic nephropathy. Kidney Int 2009;76:383-394.

- 34 Yuen PS, Dunn SR, Miyaji T, Yasuda H, Sharma K, Star RA: A simplified method for HPLC determination of creatinine in mouse serum. Am J Physiol Renal Physiol 2004;286:F1116-F1119.

-35 Qi Z, Fujita H, Jin J, Davis LS, Wang Y, Fogo AB, Breyer MD: Characterization of susceptibility of inbred mouse strains to diabetic nephropathy. Diabetes 2005;54:2628-2637.

- 36 Fragiadaki M, Witherden AS, Kaneko T, Sonnylal S, Pusey CD, Bou-Gharios G, Mason RM: Interstitial fibrosis is associated with increased COL1A2 transcription in AA-injured renal tubular epithelial cells in vivo. Matrix Biol 2011;30:396-403.

- 37 Pozdzik AA, Salmon IJ, Husson CP, Decaestecker C, Rogier E, Bourgeade MF, Deschodt-Lanckman MM, Vanherweghem JL, Nortier JL: Patterns of interstitial inflammation during the evolution of renal injury in experimental aristolochic acid nephropathy. Nephrol Dial Transplant 2008;23:2480 2491.

- 38 Martinez MC, Nortier J, Vereerstraeten P, Vanherweghem JL: Steroid therapy in chronic interstitial renal fibrosis: the case of Chinese-herb nephropathy. Nephrol Dial Transplant 2002;17:2033-2034.

- 39 Gillerot G, Goffin E, Moulin P, Arlt VM, Phillips DH, Cosyns JP, Devuyst O: Aristolochic acid nephropathy and the peritoneum: functional, structural, and molecular studies. Kidney Int 2003;64: 1883-1892.

-40 Donadio JV Jr, Torres VE, Velosa JA, Wagoner RD, Holley KE, Okamura M, Ilstrup DM, Chu CP: Idiopathic membranous nephropathy: the natural history of untreated patients. Kidney Int 1988;33: $708-715$.

-41 Gretz N, Zeier M, Geberth S, Strauch M, Ritz E: Is gender a determinant for evolution of renal failure? A study in autosomal dominant polycystic kidney disease. Am J Kidney Dis 1989;14:178-183.

-42 Neugarten J, Acharya A, Silbiger SR: Effect of gender on the progression of nondiabetic renal disease: a meta-analysis. J Am Soc Nephrol 2000;11:319-329.

-43 Rekola S, Bergstrand A, Bucht H: Deterioration of GFR in IgA nephropathy as measured by $51 \mathrm{Cr}$ EDTA clearance. Kidney Int 1991;40:1050-1054.

-44 Stringer KD, Komers R, Osman SA, Oyama TT, Lindsley JN, Anderson S: Gender hormones and the progression of experimental polycystic kidney disease. Kidney Int 2005;68:1729-1739.

-45 Oudar O, Elger M, Bankir L, Ganten D, Ganten U, Kriz W: Differences in rat kidney morphology between males, females and testosterone-treated females. Ren Physiol Biochem 1991;14:92-102.

-46 de Jonge H, Vanrenterghem Y: Aristolochic acid: the common culprit of Chinese herbs nephropathy and Balkan endemic nephropathy. Nephrol Dial Transplant 2008;23:39-41. 